\title{
Vegetable-Origin Foam Employed in Dye Extraction in Tanning and Leather Processing Facilities
}

\author{
José M. Cangemi \\ Faculdades COC, Ribeirão Preto/SP \\ Antonia M. dos Santos \\ Instituto de Biociências, Unesp-Rio Claro/SP \\ Salvador C. Neto, Daniele Oshita \\ Instituto de Química de São Carlos, USP
}

\begin{abstract}
This study addressed the use of conventional and vegetable origin polyurethane foams to extract C. I. Acid Orange 61 dye. The quantitative determination of the residual dye was carried out with an UV/Vis absorption spectrophotometer. The extraction of the dye was found to depend on various factors such as $\mathrm{pH}$ of the solution, foam cell structure, contact time and dye and foam interactions. After 45 days, better results were obtained for conventional foam when compared to vegetable foam. Despite presenting a lower percentage of extraction, vegetable foam is advantageous as it is considered a polymer with biodegradable characteristics.
\end{abstract}

Keywords: Extraction, polyurethane foam, dye.

\section{Introduction}

All existent animal and vegetable life on the Earth are constituted of great percentages of water. On average, 60 to $70 \%$ of the weight of a human being is constituted of water molecules. Despite its apparent abundance, potable water is becoming scarce in various places on earth, given that only $3 \%$ of water on the planet is available as fresh water ${ }^{[1]}$. Of this $3 \%$, only $2 \%$ consists of rivers, lakes and groundwater available for human consumption; almost $1 \%$ is snow and permanent ice cover and $0.0005 \%$ is water vapor present in the atmosphere ${ }^{[2]}$.

This scarcity of water is principally the due to the worldwide increase in the human population and resulting waste and pollution of the waters. The treatment of effluents is one of the most important issues related to pollution control. The great volume of wastewater effluent generated by tanning facilities (an average of $600 \mathrm{~L}$ of water is used in the processing of just one cattle hide), is composed of diverse harmful elements and causes a great environmental impact $^{[3]}$. It is important to note that tanning activities are an expanding sector in Brazil: The number of hides processed increased from 16,010,000 (sixteen million and ten thousand) in 1984 , to $32,500,000$ (thirty-two million, five hundred thousand) hides in the year 2000, a real growth of $103 \%$ in 16 years $^{[4]}$.

Among the most harmful compounds present in the wastewater of leather processing facilities are the coloring agents that are applied in one of the final stages of the treatment of leather, called, dying. The majority of coloring agents are resistant to biodegradation due to the presence of substituted chemical groups that are difficult to remove by biological treatment, and their photochemical degradation in aqueous solution which may occur in lakes and rivers, is a very slow process because synthetic dyes are designed to have high stability under light. The colored effluents, even in concentrations below $1 \mathrm{ppm}$ are visible in an aqueous solution $^{[5]}$ and can generate a series of consequences to the receptor bodies, such as a reduction in photosynthetic activity and the growth of algae.

Other industrial sectors such as textiles, for example, coexist with the problem of colored effluents, and various efforts have been made to attempt to reduce the dying process itself, such as electrochemical treatment ${ }^{[6]}$ and absorption of coloring substances on the surface of natural solids ${ }^{[7]}$. The use of activated charcoal in effluent treatment, due to its adsorption capacity, has been given great attention by the industry. However, because the chemical surface of carbon is positive, the inability to adsorb cationic coloring agents is a very significant limitation ${ }^{[8]}$, and when analyzed from the viewpoint of environmental damage, this process corresponds to a non-destructive process in that the disposal of the final solid phase waste is still a problem with no solution $^{[9]}$.

Flexible polyurethane foam derived from castor oil has demonstrated the capacity adsorb molecules of textiles present in aqueous media ${ }^{[10]}$. With the growth of environmental responsibility since the 90 's, polyurethane foams have become a focus of research because they possess the desirable characteristics of removing pre-concentrations and sepa-

Autor para correspondência: José M. Cangemi, Faculdades COC, Rua Abrahão Issa Halack 980 - Ribeirânia, CEP: 14096-160, Ribeirão Preto, SP, Brasil. 
rating a variety of substances. The sphericity and the open cellular structure offer a greater flow and better concentration ability compared to other sorbent solids ${ }^{[11]}$.

The utilization of polyurethane resins results in greater adsorptive capacity making the process more advantageous than activated carbon ${ }^{[12]}$. Adsorption is the result of a favorable interaction between an adsorbent solid and a species of dissolved solute. Many interactions such as electrostatic attraction, covalent chains of hydrogen among others can contribute to adsorption and the process of desorption ${ }^{[13]}$. Fong $\&$ Chow $^{[14]}$ relate that there are many studies on extraction but few of these studies have discussed the mechanisms of extraction.

The synthesis of urethanes involves the reaction of functional isocyanate groups with functional hydroxyl groups.

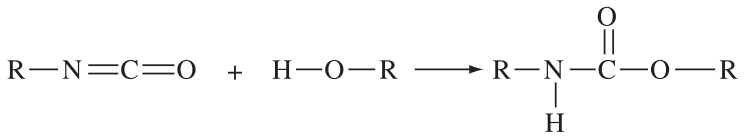

The present study utilized polyester-type polyurethane formulated from castor oil, synthesized by the Analytic Chemistry and Technology Polymers Group of the University of São Paulo at São Carlos, whose structure possesses molecules derived from a vegetable oil that make it susceptible to microorganism attack, and thus can be considered to be a polymer with biodegradable characteristics ${ }^{[15]}$. It is synthesized from the reaction of polyols with TDI diisocyanates(toluene diisocyanate) and MDI (4,4 diphenylmethane diisocyanate). The composition can be varied to obtain foams with different characteristics.

The objective of this study was the extraction of dye utilized in tanning facilities by conventional petroleum-derived and vegetable-origin polyurethane foams. The dye studied was C.I. Acid Orange 61 (sold under the brand name of Luganil Orange GGC Basf), which is listed in the Color Index ${ }^{[16]}$ as code 19320. In accordance with the reference cited, the dye utilized is obtained from metanilic acid and 8-quilinol of the family of azo dyes, that are characterized as presenting one or more groupings (- $\mathrm{N}=\mathrm{N}-$ ) linked to aromatic systems. The structure of the dye is shown in Figure 1.

The ionizable substitution groups make the dye watersoluble and are of vital importance in the dye application method in proteic and synthetic polyamide fibers through ionic exchange ${ }^{[17]}$. The azo dyes represent around $60 \%$ of the dyes currently utilized in the world ${ }^{[18]}$. Research studies have sho-

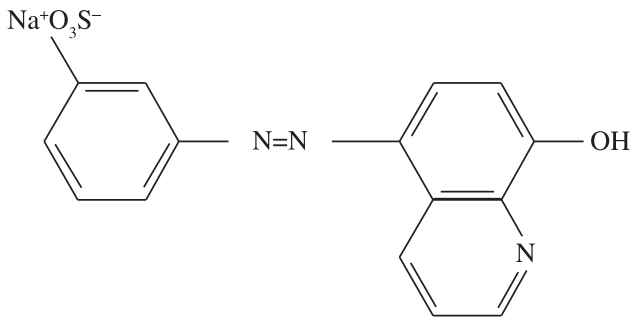

Figure 1. Structure of C.I. Acid Orange 61 Dye. wn that azo dyes and their sub-products may be carcinogenic and/or mutagenetic ${ }^{[19,20]}$.

\section{Experimental}

\section{Polymeric material}

Polyester type polyurethane formulated from castor oil, synthesized by the Analytic Chemistry and Technology Polymers Group of the University of São Paulo at São Carlos was utilized. Conventional Polyether Foam, derived from petroleum, was acquired in a construction materials store in the city of Franca, SP, and had been produced by Metalic Acessórios para Laboratório Ltda, and no detailed information was available on its composition.

The foam samples were cut into cylinders $3.0 \mathrm{~cm}$ in length and $1.0 \mathrm{~cm}$ in diameter, and a mass of approximately $0.2 \mathrm{~g}$. Before utilization, the foams underwent a procedure that eliminated the organic and inorganic residues from the synthesis of these foams, which prepared them functionally for use in the experiment. This procedure consists of washing the foams with a solution of $1 \mathrm{M}$ of acid chloride, followed by deionized water until the acid is rinsed away, then washing with ethanol and air-drying.

\section{Dye}

The dye utilized was C.I. Acid Orange 61 (brand name: Luganil Orange GGC Basf), supplied by Tropical Ltda, Franca, SP, Brazil. The dye was dissolved in deionized water and stocked in concentrations of $1 \mathrm{mg} / \mathrm{mL}$, and diluted into concentrations of $10,20,30,40,50$ and $60 \mu \mathrm{g} \cdot \mathrm{mL}^{-1}$ for use. The functionalized foam samples were placed in $10 \mathrm{~mL}$ of the diluted solutions in the different concentrations, where they remained for 45 days. The flasks utilized in the experiment were made of brown glass and were maintained in a refrigerator at a temperature of approximately $12{ }^{\circ} \mathrm{C}$; these procedures being important to impede any decomposition of the dye by light or variations in the concentrations due to temperature.

\section{Measurement of residual dye}

The quantitative determination of residual dye in all trials were measured by absorption UV/Vis spectrometry, registered by an UV/Vis Metrolab 1700 spectrophotometer, utilizing $1 \mathrm{~cm}$ de optic path quartz cuvette and deionized water as the reference. The most convenient expression of this technique is the Lambert-Beer law, which establishes a relation between transmittance or absorbance, the thickness of the sample (optic path) and the concentration of the adsorbing species ${ }^{[21]}$, as shown in Equation 1:

$$
\mathrm{A}=\varepsilon b c
$$

where $c$ is the concentration of the sample (generally expressed in moles per liter), $b$ is the optical path (generally 
expressed in centimeters) and $\varepsilon$ (epsilon) is known as molar absorptivity, expressed in units of $\mathrm{M}^{-1} \mathrm{~cm}^{-1}$.

The sweeping was carried out with a wavelength of 200 to $800 \mathrm{~nm}$ in intervals of $1 \mathrm{~nm}$, and the readings presented maximum wavelength of $464 \mathrm{~nm}$ in the visible spectrum (responsible for color), which is used for measurement, at a temperature of $25^{\circ} \mathrm{C}$. The quantity of the original solution was measured before the addition of the foams and the remaining solution was measured 45 days after the addition of the foams.

\section{pH Measurements}

The values for $\mathrm{pH}$ were measured before the experiment (solutions without foams) and after (foam in contact with the solution for 45 days). A Nova Técnica $\mathrm{pH}$ meter was used and the measurements were made at a temperature of $25^{\circ} \mathrm{C}$.

\section{Scanning electron microscope (SEM)}

The samples of polyurethane foams underwent analysis by a LEO 440 Scanning Electron Microscope.

\section{Foam characterization}

The foams were characterized according to density and a Scanning Electron microscope technique was used to measure the diameter of the pores. The density measurements were obtained from the relation of the quantity of mass occupied by the samples to the volume occupied by the samples using Equation 2:

$$
\mathrm{d}=\frac{\mathrm{m}}{\mathrm{V}}
$$

Mass (g) from the arithmatic mean of five samples of foam and volume $\left(\mathrm{cm}^{3}\right)$ was obtained by multiplying the height of the cylinder by the area of the cylinder:

$$
\mathrm{V}=\mathrm{h} \pi \mathrm{r}^{2}
$$

where $h$ corresponds to the height of the cylinder and $r$ is the radius.

\section{Results and Discussion}

\section{Polyurethane foams}

The density and pore diameter measurements are presented in Table 1 for each category of vegetable and conventional foam.

Table 1. Measurement data for characterization of polyurethane, conventional and vegetable foams.

\begin{tabular}{lcc}
\hline \multicolumn{1}{c}{ Foam } & Density $\left(\right.$ g.cm $\left.^{-3}\right)$ & Pores $(\mathbf{n m})$ \\
\hline PU-vegetable & 0.0750 & 0.66 \\
PU-conventional & 0.0120 & 1.1 \\
\hline
\end{tabular}

\section{Dye extraction}

A calibration curve in accordance with the Law of Lambert-Beer was constructed for a chart of known concentrations of dye solution versus the foam absorbence as measured by spectrometer (Concentration x Absorption). Using the calibration curve, the quantity of dye remaining unabsorbed can be known ${ }^{[22]}$.

To obtain the calibration curve for C.I. Acid Orange 61 readings were taken of absorbency at six different concentrations of dye. Due to the highly significant coefficient of correlation $(r=0.999)$, a linear relation between absorption and concentration can be observed in Figure 2.

The percentage of extraction $(\% \mathrm{E})$ or proportion extracted from the dye was calculated by the absorbance reading (A) of the analyte before and after extraction ${ }^{[23]}$, as shown by the equation:

$$
\% \mathrm{E}=\left[\left(\mathrm{A}_{\text {initial }}-\mathrm{A}_{\text {final }}\right) / \mathrm{A}_{\text {initial }}\right] \times 100
$$

where $\mathrm{A}_{\text {initial }}$ corresponds to the initial absorbance and $\mathrm{A}_{\text {final }}$ corresponds to the final absorbance. Table 2 shows the percentages of extraction for the foams tested at various concentrations of analyte. Therefore, when we refer to $40 \%$ absorption efficiency, we mean the foam absorbed $40 \%$ of the initial dye concentration.

From the results shown in Table 2, greater extraction occurred with conventional foam, in relation to the extraction verified for vegetable foam.

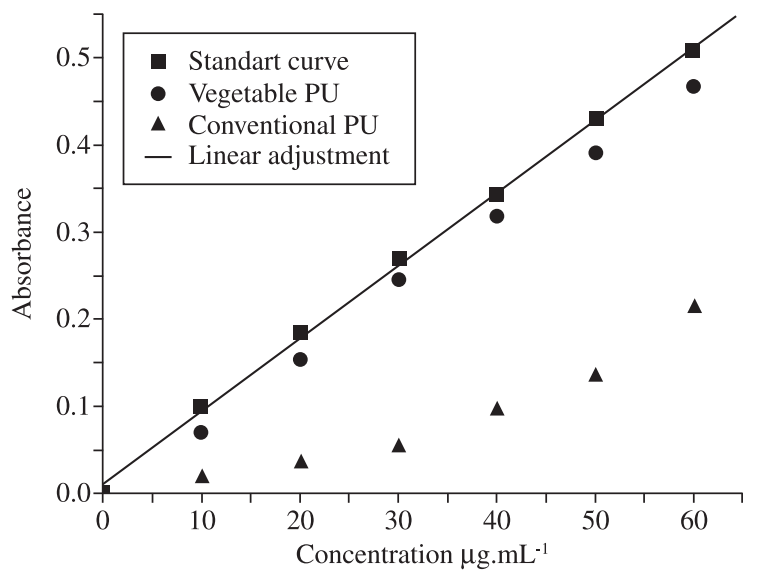

Figure 2. Absorbance curves in function of concentration, in comparison to standard curve and the curves obtained after adsorption.

Table 2. Extraction percentages, after 45 days.

\begin{tabular}{ccc}
\hline $\begin{array}{c}\text { Concentration } \\
\left(\boldsymbol{\mu g} . \mathrm{mL}^{-1}\right)\end{array}$ & $\begin{array}{c}\text { \% of Extraction } \\
\text { after 45 days } \\
\text { vegetable foam }\end{array}$ & $\begin{array}{c}\text { \% of Extraction } \\
\text { after 45 days } \\
\text { conventional foam }\end{array}$ \\
\hline 10 & 33.3 & 85.7 \\
20 & 27.1 & 83.3 \\
30 & 22.0 & 83.1 \\
40 & 21.9 & 76.4 \\
50 & 22.8 & 73.6 \\
60 & 22.4 & 64.7 \\
\hline
\end{tabular}


In comparison of the standard curve (without foam) to the curves presented after 45 days in contact with the foams, extraction occurred in both cases, with a greater proportion of extraction by conventional foam. This fact may be related, among other things, to the cell structure of the foams utilized. In Figure 3b, note that the polyether foam (conventional) presents an open hexagonal pore, while in Figure 3a, the polyester foam (vegetable) has a globular structure (spherical cells) which makes diffusion of the solution throughout the foam difficult and diminishes the efficiency of adsorption ${ }^{[24]}$. The shape of the pore is added to its size to calculate total contact area. Conventional foam has a mean size of $1.1 \mathrm{~nm}$, almost twice the size of vegetable foam pores (0.66) (Table 1). Thus, one could speculate there is a greater absorption efficiency with a larger cell because the total contact surface for the absorbent and dye is greater.

The exact mechanism by which these processes occur is still hypothesized as: adsorption, electrostatic attraction, absorption, cationic quelation, ionic exchange, van der Waals interactions or even a set of these interactions. Chow \& Fong ${ }^{[14]}$, who have already published various studies in the literature on the extraction of contaminants with polyurethanes, state that there are a considerable number of studies in

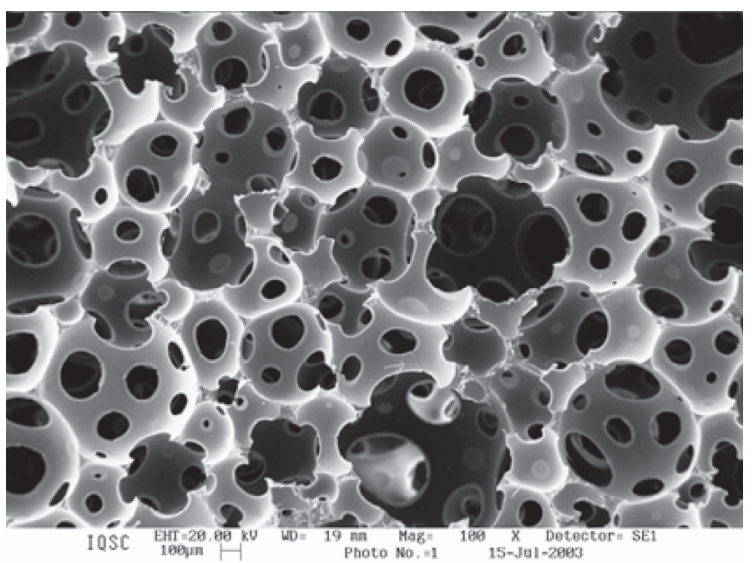

(a)

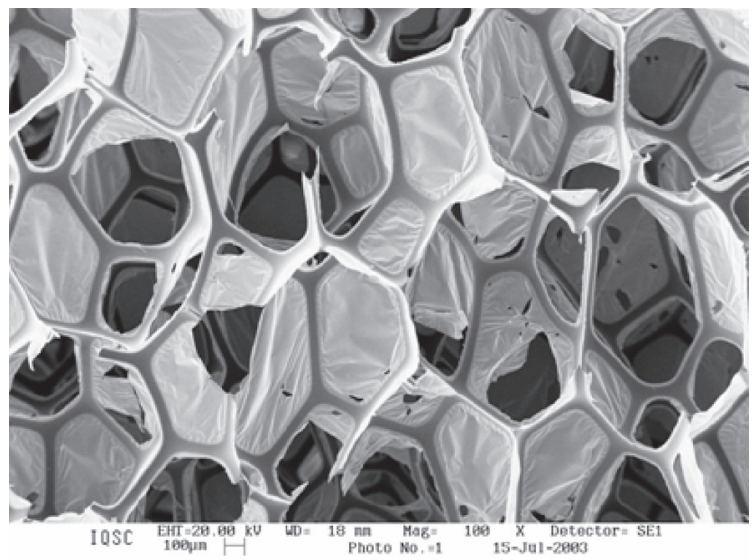

(b)

Figure 3. Scanning electron microscope $(100 \mathrm{x})$ : a) vegetable foam; e b) conventional foam. the literature on extraction of contaminants by polyurethanes but few studies which discuss the extraction mechanisms themselves.

Figure 4 shows graphics of $\mathrm{A} / \mathrm{A}_{0}$ (normalized absorbance) in function of time, where A refers to absorbance variance with time, and $A_{0}$ refers to the absorbance of the initial concentrations of samples analyzed $(t=0 \mathrm{~h})$. In Figure $4 \mathrm{a}$ data referent to adsorption of the dye utilizing foam derived from castor oil, and in Figure 4b, data refers to the adsorption of the dye utilizing conventional foam. Comparing both foams, we found that the smaller the concentration of dye, the more effective the adsorption of the dye by the foam, in both cases.

\section{Effect of $\mathrm{pH}$ on extraction}

Table 3 shows the $\mathrm{pH}$ values measured in the dye solutions, before and after contact with the foams on the $45^{\text {th }}$ day of the experiment.

After 45 days, conventional foam leaves the solution with a more acid $\mathrm{pH}$ that may be related to a characteristic in the formulation of commercial foam (a formulation which was

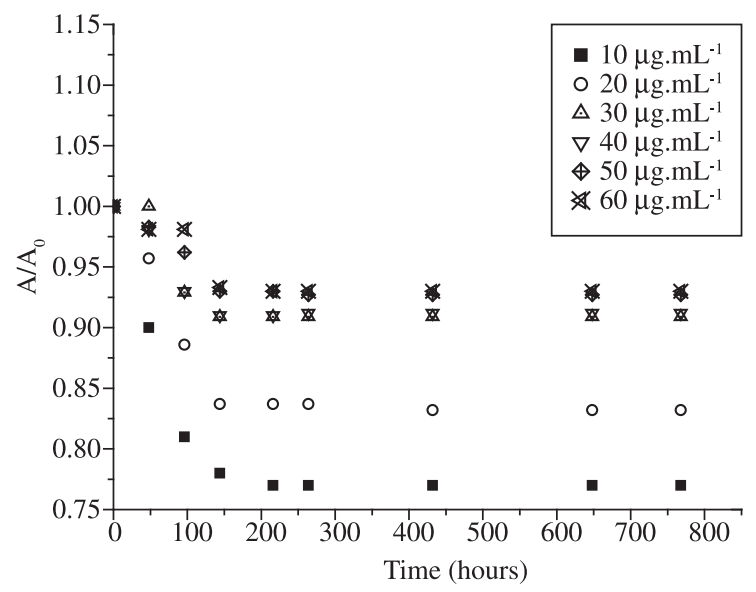

(a)

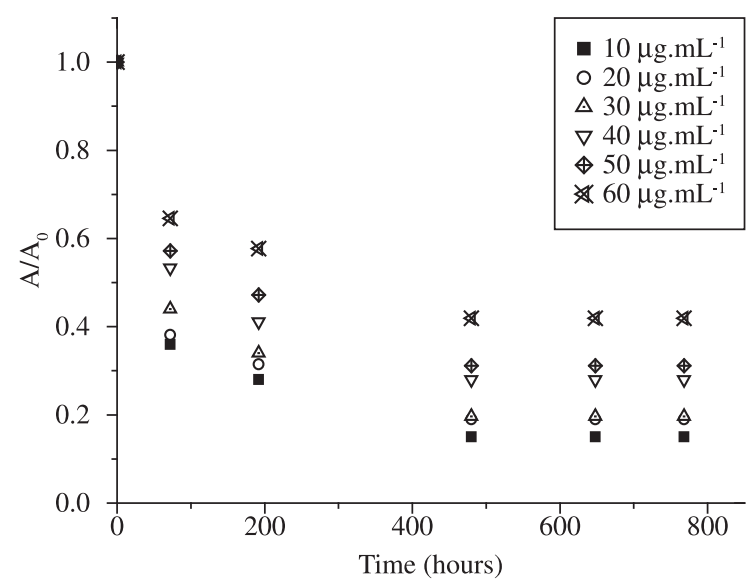

(b)

Figure 4. Normalized absorbance curves (A/A $)$ in function of dye adsorption time in various concentrations: a) adsorption utilizing vegetable foam; e b) adsorption utilizing conventional foam. 
Table 3. $\mathrm{pH}$ Measurements.

\begin{tabular}{cccc}
\hline Concentration $\left(\boldsymbol{\mu g . m L ^ { - 1 } )}\right.$ & $\mathbf{p H}$ of samples without foams & $\begin{array}{c}\mathbf{p H} \text { of solutions with vegetable foam } \\
\text { after 45 days }\end{array}$ & $\begin{array}{c}\mathbf{p H} \text { of solutions with conventional } \\
\text { foam after 45 days }\end{array}$ \\
\hline 10 & 7.06 & 7.63 & 5.71 \\
20 & 7.20 & 7.60 & 3.84 \\
30 & 7.24 & 7.67 & 3.50 \\
40 & 7.30 & 7.46 & 3.41 \\
50 & 7.39 & 7.37 & 3.35 \\
60 & 7.85 & 7.41 & 3.34 \\
\hline
\end{tabular}

not supplied by the manufacturer). In the case of vegetable foam exposed to the same conditions, little variation was observed in the values, and the solutions continued to be lightly basic. Thus, dye extraction is increased with acid $\mathrm{pH}$. Oshita ${ }^{[25]}$, obtained a maximum extraction (\%) of azo dye in a $\mathrm{pH}$ solution of 2.0 utilizing polyurethane foams. Accioly ${ }^{[26]}$, studied the adsorption of C.I. Acid Blue 193 by polyurethane foam and found that the $\mathrm{pH}$ directly affected the adsorption efficiency. He found that an acid $\mathrm{pH}$ had $74.2 \%$ efficiency in absorbing the dye in comparison to only $38 \%$ for a base solution.

In the case of the present work, it can be deduced that the acid surface of polyurethane acquires a positive charge, with a consequently greater interaction between the surface and anionics groups (hydroxyl, azo and sulfite) and C.I. Acid Orange 61 dye. As a result greater interaction occurred between the adsorvent and adsorvate, and a greater percentage of extraction $(\% \mathrm{E})$.

\section{Conclusions}

The results presented demonstrate the viability of making a pre-treatment of contaminated effluents utilizing polyurethane foams. Tests of dye extraction by vegetable-derived polyurethane (polyester) and conventional (polyether) foams were carried out for a duration of 45 days. The percentage of extraction $(\% \mathrm{E})$ obtained was superior for conventional polyurethane and the more diluted the dye, the greater the percentage of extraction by the foams. Thus, the best result was obtained at a concentration of $10 \mu \mathrm{g} \cdot \mathrm{mL}^{-1}$, according to spectrophotometric readings of adsorption at $85.7 \%$ for commercial foam and $33.3 \%$ for natural origin foam.

The extraction mechanism for dye by polyurethane foam has various physiochemical hypotheses such as adsorption, absorption, cationic quelation, electrostatic attraction or even a simultaneous occurrence of these actions.

In spite of having presented a lower $\% \mathrm{E}$ in comparison to conventional foam, vegetable-derived foam has two factors in its favor that should be considered: first, the physical properties of this foam can be modified to extract more dye, which can be tested in future studies; and second, its chemical structure makes it susceptible to attack from microorganisms, and it is therefore considered a polymer with biodegradable characteristics that integrates into natural environment after undergoing decomposition. In the case of conventional PU foam, like any polymer derived from petroleum, once discarded, it does not degrade for decades or centuries, seriously aggravating the problem of waste disposal.

\section{Acknowledgements}

The authors thank Prof. Gilberto O. Chierice, PhD for making the polyurethane foam derived from castor oil available, CAPES for the PhD scholarship, the Curtume Tropical Ltda in the city of Franca-SP, Brazil for supplying the dye utilized and the University of Franca (UNIFRAN) which kindly allowed us use of their laboratories for spectrophotometric measurement.

\section{References}

1. Tundisi, J. G. - “Água no século XXI - Enfrentando a escassez", Rima Editora, São Carlos (2003).

2. Rocha, J. C.; Rosa, A. H. \& Cardoso, A. A. - "Introdução à Química Ambiental", Bookman, Porto Alegre (2004).

3. Palermo, H. F. - "Avaliação econômica e ambiental das atividades curtidoras e acabadoras de couros na região de Franca - São Paulo", Tese de Doutorado, Universidade Estadual Paulista, Rio Claro (2001).

4. Sindicato das Indústrias de Curtimento de Couros e Peles do estado de São Paulo - Sindicouro. - "Estatísticas sobre a produção de couros no Brasil", Sindicouro, São Paulo (2001).

5. Holme, I. - Applied Chemistry, 7, p.111, (1984).

6. Lin, S. H. \& Peng, C. F. - Wastewater Research, 28, p.277, (1994).

7. Nassar, M. M. \& El-Geund, M. S. Journal of Chemical Technology and Biotechnology, 50, p.257, (1991).

8. Al-Degs, Y.; Khraisheh, M. A. M.; Allen, S. J. \& Ahmad, M. N - Water Research, 34, p.927, (2000).

9. Kunz, A.; Peralta-Zamora, P.; Moraes, S. G. \& Durán, N. - Química Nova, 25, p.78, (2002).

10. Santos, A. M.; Claro Neto, S.; Chierice, G. O. \& Domingos-Silva, D. - "Aplicação de espumas de poliuretano na adsorção de corantes têxteis”, in: Anais do XIV Congresso Brasileiro de Engenharia e Ciência dos Materiais , p.6, São Pedro (2000). 
11. Werbowesky, R. \& Chow, A. - Talanta, 43, p.263, (1996).

12. Oliveira, E. J.; Chierice, G. O. - "Synthesis of new ion resin for recovery of noble metal, ion Exchange development and application", Greig, J.A., (Ed.), Royal Society of Chemistry, U.K. (1996).

13. Meyers, D. - "Surface, Interfaces and Colloids Principles and Applications", John Wiley \& Sons, New York (1999).

14. Fong, P. \& Chow, A. - Talanta, 39, p.497, (1992).

15. Cangemi, J. M; Santos, A. M.; Claro Neto, S. \& Chierice, G. O. - "Biodegradation of Polyurethane Derived From Castor Oil", in: Programa e Resumos do XV Congresso Brasileiro de Engenharia e Ciência dos Materiais, p.20, Natal, (2002).

16. Society of Dyers and Colourists. - "Colour Index", England, Society of Dyers and Colourists, U.K. (1971).

17. Guaratini, C. C. I. \& Zanoni, M. V. - Química Nova, 23, p.71, (2000).

18. Vandevivere, P. V.; Bianch, R. \& Verstraete, W. J. - Journal of Chemical Technology and Biotechnology, 72, p.289, (1998).

19. Houk, V. S. - Mutat. Res., 277, p.91, (1992).
20. Brown, M. A. \& Devito, S. C. - Critical Reviews in Environmental Science and Technology, 23, p.249, (1993).

21. Basset, J.; Denney, R. C.; Jeffery, G. H. \& Mendham, J. - “Análise Inorgânica Quantitativa Vogel”, Guanabara, Rio de Janeiro (1986).

22. Immich, A. P. S. - "Remoção de Corantes de Efluentes Têxteis Utilizando Folhas de Azadirachta indica como Adsorvente", Dissertação de Mestrado, Universidade Federal de Santa Catarina, Florianópolis (2006).

23. Schumack, L. \& Chow, A. - Talanta, 34, p.957, (1987).

24. Oliveira, E. J. - "Processos de partição para separação e concentração de ouro em minério usando foams de poliuretanos", Dissertação de Mestrado, Universidade de São Paulo, São Carlos (1993).

25. Oshita, D. - "Extração de contaminantes de águas de curtumes usando foams de poliuretana derivadas de óleo vegetal", Dissertação de Mestrado, Universidade de São Paulo, São Carlos (2005).

26. Accioly, M. G. - "Adsorção do corante Luganil azul por espuma de poliuretano", Monografia de Conclusão de Curso, Universidade Estadual Paulista, Rio Claro (2008).

Enviado: 26/02/09

Reenviado: 16/05/09

Aceito: $20 / 05 / 09$ 